\title{
Photodermatitis following the Use of Pirfenidone in a Patient with Idiopathic Pulmonary Fibrosis: An Ultraviolet Recall Reaction
}

\author{
Idiyopatik Pulononer Fibrozisli bir Hastada Pirfenidon Altında Gelişen \\ Fotodermatit: Bir Ultraviyole Hatırlama Reaksiyonu
}

Ayse Baccioglu', Ayse Füsun Kalpaklioglu', Tuba Devrim²

\begin{abstract}
Ultraviolet recall is a photodermatitis reaction that can occur in prior ultraviolet burned skin during the administration of systemic medication. No such reaction has been reported with pirfenidone. We report here on a 75-year-male patient who developed acute erosive erythema on his face, forearms and hands under pirfenidone treatment for idiopathic pulmonary fibrosis after 4 months. The initial diagnosis was drug eruption, since it developed after the initiation of pirfenidone, in accordance with hypereosinophilia and solar dermatitis on a skin biopsy, all of which improved with discontinuation. However, the patient tolerated the rechallange test with pirfenidone. The presence of necrotic keratinocytes in a skin biopsy and exaggerated dermatitis was unlikely for photodermatitis, but supported an ultraviolet recall reaction. Pirfenidone was resumed in a tapered dose, and the patient was successfully followed up for 5 months for a relapse of skin reaction, as well as IPF disease activity. This case is important in indicating that the drug can be tolerated with dose adjustment in the presence of an ultraviolet recall reaction in contrast to discontinuation need in drug allergy.
\end{abstract}

Key words: Drug eruption, phototoxicity, pirfenidone, ultraviolet recall phenomen.

\section{Özet}

Ultraviyole hatırlama reaksiyonu, önceden ultraviyole ışınına bağlı yanık gelişmiş kişinin sistemik ilaç kullanımı sonrası benzer kliniğin gelişmesiyle karakterize bir fotodermatittir. Pirfenidonla bu reaksiyon daha önce bildirilmemiştir. Yetmiş beş yaşındaki erkek hastada idiopatik pulmoner fibrozis için pirfenidon başlandıktan 4 ay sonra güneş gören deri alanlarında akut erosiv eritem gelişmişti. Önce pirfenidona bağlı ilaç erüpsiyonu olduğu düşünüldü, çünkü; eşlik eden hipereozinofilisi, deri biyopsisinde solar dermatitis sonucu vardı ve belirtiler pirfenidondan sonra gelişmiş ve ilacın kesilmesinden sonra düzelmişti. Ancak, oral provokasyon testinde hastanın ilacı tolere etmesi, deri lezyonlarının basit bir solar dermatitis için çok şiddetli olması ve deri biyopsisinde nekrotik keratinositlerin görülmesi ultraviyole hatırlama reaksiyonunu düşündürdü. Pirfenidon dozu düşürülerek yeniden başlandı, 5 aylık takip süresinde deri lezyonları nüks etmedi ve IPF hastalığında atak gelişmedi. Illaç alleriisinden farklı olarak pirfenidon ultraviyole hatırlama reaksiyonunda, tedaviye doz ayarlamasıyla devam edilebileceğini göstermesi açısından bu olgu önemlidir.

Anahtar Sözcükler: Illaç erupsiyonu, fototoksisite, pirfenidon, ultraviyole hatırlama reaksiyonu.
'Department of Pulmonary Diseases, Kırikkale University Faculty of Medicine, Division of Immunology and Allergy, Kırıkale, Turkey ${ }^{2}$ Department of Pathology, Kırıkkale University Faculty of Medicine, Kırikkale, Turkey
'Kırıkkale Üniversitesi Tıp Fakültesi, Göğüs Hastalıkları Anabilim Dalı, İmmünoloji ve Allerii Bilim Dalı, Kırıkkale ${ }^{2}$ Kırıkkale Üniversitesi Tıp Fakültesi, Patoloji Anabilim Dalı, Kırıkale

Submitted (Başvuru tarihi): 04.12.2019 Accepted (Kabul tarihi): 25.02.2020

Correspondence (iletişim): Ayse Baccioglu, Department of Pulmonary Diseases, Kırıkkale University Faculty of Medicine, Division of Immunology and Allergy, Kırıkkale, Turkey 
Ultraviolet recall reaction is a type of photodermatitis that occurs in ultraviolet-burned skin after the administration of systemic medications (1). Such reactions are rare, and have no report by pirfenidone, which is an oral antifibrotic agent approved for patients with idiopathic pulmonary fibrosis (IPF) (2). We present here a case of ultraviolet recall photodermatitis by pirfenidone.

\section{CASE}

A 75-year-old Caucasian man was admitted with an extraordinary sunburn like scaly erythema on his face, forearms and hands that had emerged a few days earlier. He had no recent sun exposure, and limited physical movement that made it almost impossible for him to go outside. He had been undergoing treatment with pirfenidone (2403 mg/day) for IPF besides inhaled tiotropium, and budesonide/formoterol for 4 months, and subsequently developed a desquamative, burning and erosive erythema limited on sun exposed areas such as the forehead, scalp, face, neck, dorsa of the forearms and hands (Figure 1). He had also vitiligo patches on his face, neck and forearms surrounded by a reddish ultralight-colored skin.

Laboratory tests revealed elevated eosinophil counts $(1400 / \mathrm{mL})$ and a normal total leukocyte count $(8.600 / \mathrm{mL})$, in addition to vitamin $\mathrm{D}$ deficiency (10.55ng/dL, normal; 25-80ng/dL). Renal and hepatic function tests were within normal limits. Serum ANA, ccp, ANCA, ACE, anti-ds-DNA/jol/scl70/sm/ssa/ssb were also negative. Chest $x$-ray and pulmonary function tests were stable when compared to previous values.

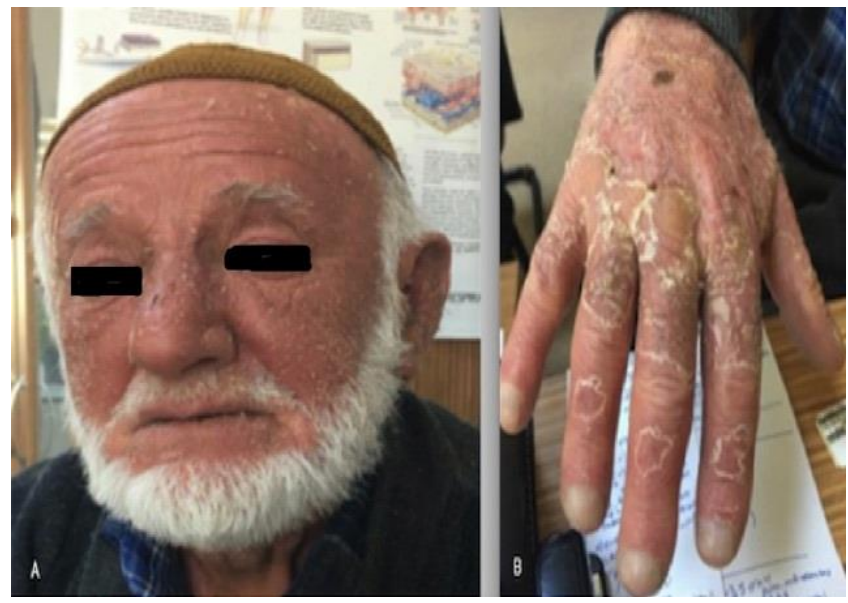

Figure 1: Severe erythema of the face (a), desquamative and erosive erythema on the back of hands (b)
Histopathological findings of the biopsied forearm skin revealed solar dermatitis with keratinocyte necrosis, spongiosis with a lichenoid reaction, focal parakeratosis, and irregular acanthosis in the epidermis, vacuolization, perivascular lymphocytic cell infiltration and no specific deposition of immunoglobulin or complements on the basement membrane or vessel walls (Figure 2).

Pirfenidone was discontinued, and the patient was treated with $40 \mathrm{mg} /$ day $(0.5 \mathrm{mg} / \mathrm{kg} /$ day $)$ of intravenous methylprednisolone for 10 days, with slight improvement. The reaction was concluded to be a phototoxicity reaction in the sun-exposed areas, in addition to solar dermatitis on a skin biopsy. It was also considered to be a drug eruption, having developed during pirfenidone treatment, in accordance with serum hypereosinophilia, and after improvement was noted upon discontinuation. However, the reaction time as of March was unexpected for photoreactivity given the rarity of sunny days, and the solar dermatitis clinic was so severe with rapid progression. Accordingly, to confirm the diagnosis, an oral provocation test was carried out 4 weeks after recovery in May, and the patient was found to tolerate pirfenidone. The reaction was thus concluded to be an ultraviolet recall reaction. The presence of necrotic keratinocytes in the skin biopsy was unlikely for photodermatitis, but also supported this diagnosis. Even though the patient denied sun exposure, the weather had been slightly sunny a few days before the reaction, and this limited sun may have recalled the solar dermatitis experienced in previous years to his extremely white skin with vitiligo.

Pirfenidone was resumed in a tapered dose (1602 $\mathrm{mg} /$ day) following the complete regression of skin lesions and the suggestion of ultraviolet recall dermatitis rather than of drug eruption. The patient was successfully followed up for 5 months for relapses of the skin reaction, as well as disease activity of IPF.

\section{DISCUSSION}

Even though phototoxicity due to pirfenidone is a relatively common reaction, this case report is important in its rarity in terms of the tolerability of the drug after recovery. The most common skin side-effects of pirfenidone have been reported as $7.5 \%$ rash, $4.2 \%$ photosensitivity and generalized pruritis in a single case, but no report of ultraviolet recall reaction (3-6). 


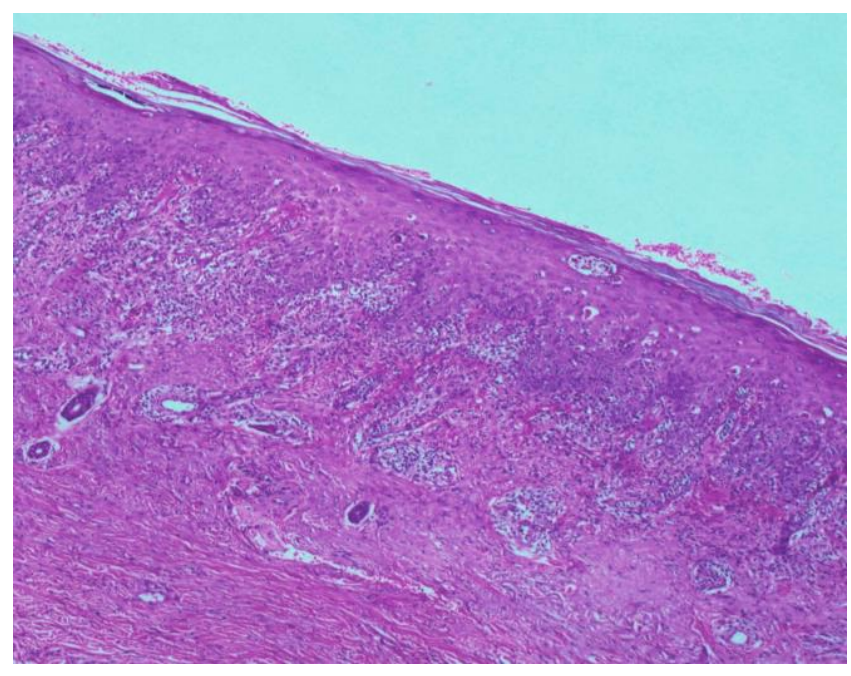

Figure 2: Focal parakeratosis and irregular acanthosis in the superficial layer, hydropic degeneration and necrotic keratinocytes in the epidermis $(H \& E \times 40)$

A diagnosis of ultraviolet recall reaction was made in the presence of previous sunburn history accompanied by systemic pirfenidone use, exaggerated clinic, skin biopsy and tolerance in a rechallange test. Necrotic keratinocytes, epidermal spongiosis and vesiculation were sensitive to ultraviolet recall reaction. Even though the history of sun exposure was unremarkable, but had lived many sunburn events in the past leaving behind photo aging findings. The duration between sunburn and drug intake varies, between days associated with chemotherapy medications, and months in ampicillin $(7,8)$. The mean duration between the initiation of pirfenidone and the development of skin manifestations was 5.5 months in literature, and 4 months in the present case (3-6).

Photosensitivity reactions take two forms: phototoxicity, occurring in sun exposed areas, whereas a generalized rash is accepted as a photoallergic reaction. Photoallergic reactions represent type IV hypersensitivity responses, requiring a specific sensitization of the drug that makes intolerance in rechallange (9). Phototoxicity has nonimmunological mechanism as direct cellular damage by ultraviolet light (10). Ultraviolet recall refers to a phototoxicity reaction that initiates with irradiation and exacerbates with systemic medication (1). The reintroduction of the drug or light exposure may not necessarily cause a recurrence. Pirfenidone is known to become reactive through the absorption of light, and the generation of reactive oxygen radicals mediates to photo irritant results (10). Another underlying mechanism is likely that pirfenidone's antifibrotic effect through suppressing some inflammatory cytokines that are associated with viral reactivation inducing cutaneous manifestation in some patients (4). Cofactors for photosensitivity are medications, lupus and some vitamin deficiencies (9). The patient refused systemic drugs other than pirfenidone before 4 weeks of the reaction time, and lupus was ruled out based on clinical and negative collagen markers. The patient's low vitamin $D$ level may be a result of long-time sun avoidance, but it has been reported that photosensitivity is not correlated with vitamin D levels (9). It may, however, be possible to become more sensitive to sunlight after winter.

Treatments of pirfenidone phototoxicity are topical emollients and in mild-moderate events, while in severe cases, systemic steroids may be required. A reduction in pirfenidone dose may be a preventive action, since it has been reported to be non-phototoxic in $30 \mathrm{mg} / \mathrm{kg}$, but phototoxic in $160 \mathrm{mg} / \mathrm{kg}$ (10). Even though ultraviolet recall does not necessitate a withdrawal of therapy, many adverse skin-related events related to pirfenidone may indicate a discontinuation of the drug, and the appliance of strict sun exposure may be helpful. In the event of a reappearance of an adverse event or exacerbation and/or progression of the disease, nintedanib, as an alternative anti-fibrotic medication, would have been started instead of pirfenidone. However, nintedanib was not the first choice therapy in the present case as the patient had been using an anticoagulation drug for cardiac disease, and nintedanib may be associated with an increased risk of bleeding.

Conclusion

This case report is interesting in that it reminds that a photosensitive reaction experienced under pirfenidone may not be due only to a drug allergy or solar dermatitis, as it may also indicate an ultraviolet recall reaction, which the drug can be tolerated in rechallange. Although it has been reported to be a rare and moderate adverse event, photosensitivity reaction can reduce quality of life and to potentially increase the risk of the development of skin cancer. Clinicians should pay particular attention to risk factors for photosensitization, such as light skin color and vitiligo, when making a decision for the treatment of IPF.

\section{CONFLICTS OF INTEREST}

None declared.

\section{AUTHOR CONTRIBUTIONS}

Concept - A.B., A.F.K., T.D.; Planning and Design - A.B., A.F.K., T.D.; Supervision - A.B., A.F.K., T.D.; Funding -; Materials - A.B.; Data Collection and/or Processing - 
A.B., T.D.; Analysis and/or Interpretation - A.B.; Literature Review - A.B.; Writing - A.B.; Critical Review - A.B., A.F.K.

\section{YAZAR KATKILARI}

Fikir - A.B., A.F.K., T.D.; Tasarım ve Dizayn - A.B., A.F.K., T.D.; Denetleme - A.B., A.F.K., T.D.; Kaynaklar -; Malzemeler - A.B.; Veri Toplama ve/veya İsleme - A.B., T.D.; Analiz ve/veya Yorum - A.B.; Literatür Taraması - A.B.; Yazıyı Yazan - A.B.; Eleştirel İnceleme - A.B., A.F.K.

\section{REFERENCES}

1. Shiohara T, Mizukawa Y. Recall phenomenon: some skin-resident cells remember previous insults. Dermatology 2003; 207:127-9. [CrossRef]

2. Noble PW, Albera C, Bradford WZ, Costabel U, Glassberg MK, Kardatzke D, et al. Pirfenidone in patients with idiopathic pulmonary fibrosis (CAPACITY): two randomized trials. Lancet 2011 ; 377:1760-9. [CrossRef]

3. Costabel U, Bendstrup E, Cottin V, Dewint P, Egan JJ, Ferguson J, et al. Pirfenidone in idiopathic pulmonary fibrosis: expert panel discussion on the management of drug-related adverse events. Adv Ther 2014; 31:375-91. [CrossRef]

4. Droitcourt C, Adamski H, Polat A, Polard E, Kerjouan M, Arnouat $B$, et al. Pirfenidone photosensitization in pa- tients with idiopathic pulmonary fibrosis a case series. $\mathrm{Br}$ J Dermatol 2018; 178:e222-3. [CrossRef]

5. Papakonstantinou E, Prasse A, Schacht V, Kapp A, Raap $U$. Pirfenidone-induced severe phototoxic reaction in a patient with idiopathic lung fibrosis. J Eur Acad Dermatol Venereol 2016; 30:1354-6. [CrossRef]

6. Tsuruta A, Washio K, Fukunaga A, Nishigori C. Pirfenidone-induced photoleukomelanoderma in a patient with idiopathic pulmonary fibrosis. J Dermatology 2016; 43:207-9. [CrossRef]

7. Basile FG, Creamer S. Docataxel/cylophomide induced ultraviolet recall dermatitis. J Clin Oncology 2011; 29:e840-1. [CrossRef]

8. Krishnan RS, Lewis AT, Kass JS, Hsu S. Ultraviolet recalllike phenomenon occurring after piperacillin, tobramycin, and ciprofloxacin therapy. J Am Acad Dermatol 2001; 44:1045-7. [CrossRef]

9. Mang R, Stege H, Krutmann J. Mechanisms of phototoxic and photoallergic reactions. In: Frosch PJ, Menné T, Lepoittevin JP. (eds) Contact Dermatitis Springer, Berlin, Heidelberg. 2006: 97-104. [CrossRef]

10. Seto $Y$, Inove R, Kato M, Yamada S, Onoue S. Photosafety assessments on pirfenidone: photochemical, photobiological, and pharmacokinetic characterization. J Photochem Photobiol B 2013; 120:44-51. [CrossRef] 